\title{
Improved Microassays Used to Test Natural Product-Based and Conventional Fungicides on Plant Pathogenic Fungi
}

\author{
Maritza Abril and Kenneth J. Curry, University of Southern Mississippi, Hattiesburg, MS 39406-5018; Barbara \\ J. Smith, Thad Cochran Southern Horticultural Laboratory, Agricultural Research Service, U.S. Department of Agri- \\ culture, Small Fruit Research Unit, Poplarville, MS 39470; and David E. Wedge, Thad Cochran National Center for \\ Natural Products Research, Agricultural Research Service, U.S. Department of Agriculture, Natural Products Utiliza- \\ tion Research Unit, University, MS 38677
}

\begin{abstract}
Abril, M., Curry, K. J., Smith, B. J., and Wedge, D. E. 2008. Improved microassays used to test natural product-based and conventional fungicides on plant pathogenic fungi. Plant Dis. 92:106112 .

Seven important plant pathogenic fungi (Botrytis cinerea, Colletotrichum acutatum, C. fragariae, C. gloeosporioides, Fusarium oxysporum, Phomopsis obscurans, and P. viticola) valuable in screening fungicides were tested. Our procedure included washing conidia to reduce germination times, incorporating Roswell Park Memorial Institute 1640 as a medium of known composition, and using coverslips in the 24-well cell culture clusters to document the effect of fungicides on fungal morphology. The natural product-based fungicide, sampangine, a sampangine analog, 4-bromosampangine, plus seven conventional fungicides (benomyl, captan, cyprodinil, fenbuconazole, fenhexamid, iprodione, and kresoxim-methyl) were tested in vitro for their ability to inhibit germination and growth of the seven fungal species. Sampangine inhibited germination in all fungi except C. acutatum. Comparison of results of germination and morphology microbioassays with results of microtiter assays suggests that some fungicides stop fungal germination, whereas others only slow down fungal growth. We hypothesize that sampangine, except against $C$. acutatum, has the same physical mode of action, germination inhibition, as the conventional fungicides captan, iprodione, and kresoxim-methyl. 4-Bromosampangine caused morphological anomalies including excessive branching of germ tubes of $C$. fragariae and splaying and branching of germ tubes of $B$. cinerea.
\end{abstract}

Additional keywords: fungal sensitivity

Fungicide discovery efforts at the USDA-ARS, National Center for Natural Products Research, in University, MS, are focused on natural products derived from plants with emphasis on compounds with fungicidal activity (29). Microtiter assays have been developed for screening large numbers of natural products that have potential use in the agrochemical industry (29). This type of assay has the quality of being an accurate, sensitive, and rapid detection system for differentiating doseresponse relationships and differences in fungal sensitivity to known fungicides

Corresponding author: K. J. Curry

E-mail: kenneth.curry@usm.edu

Mention of a trademark, proprietary product, or vendor does not constitute a guarantee or warranty of the product by the U.S. Department of Agriculture and does not imply its approval to the exclusion of other products or vendors that also may be suitable.

Accepted for publication 2 September 2007.

doi:10.1094/PDIS-92-1-0106

This article is in the public domain and not copyrightable. It may be freely reprinted with customary crediting of the source. The American Phytopathological Society, 2008. and numerous natural products (1315,17,26).

Sampangine, an alkaloid isolated from the root bark of Cleistopholis patens, and its analogs represent a group of promising natural product chemicals for control of fungi. Data obtained from in vitro bioautography and 96-well microtiter assays indicated that sampangine and its analogs have a broad-spectrum antifungal activity against several plant pathogenic fungi sensitive to benzimidazole and dicarboximide fungicides including Botrytis cinerea $\left(\mathrm{IC}_{50}<3.0 \mu \mathrm{M}\right)$, Colletotrichum acutatum $\left(\mathrm{IC}_{50}<3.0 \mu \mathrm{M}\right)$, C. fragariae $\left(\mathrm{IC}_{50}<\right.$ $3.0 \mu \mathrm{M}), C$. gloeosporioides $\left(\mathrm{IC}_{50}<3.0\right.$ $\mu \mathrm{M})$, and Fusarium oxysporum $\left(\mathrm{IC}_{50}<3.0\right.$ $\mu \mathrm{M}$ ) (Patent \# 6,844,353B2; 29).

This study made complementary use of two types of microassays: microtiter assays and microbioassays. Microtiter assays entail challenging fungi with concentrations of natural product-based and conventional fungicides in 96-well cell culture clusters and evaluating fungal growth with a microplate photometer. Microbioassays entail challenging fungi with concentrations of natural product-based and conventional fungicides in 24-well cell culture clusters and evaluating growth by direct, microscopic observation. The study was conducted to address three important issues concerning fungicide activity for microassays: (i) optimizing conidial germination for microassays; (ii) determining the sensitivity of targeted fungi to three concentration levels of sampangine, 4bromosampangine, and seven conventional fungicides by microtiter assays; and (iii) determining the effects of these fungicides on the morphology of germinated conidia, germ tube elongation, and early hyphal growth by microbioassays.

\section{MATERIALS AND METHODS}

Fungal isolates and medium. Seven fungal isolates, all cosmopolitan plant pathogens, were used in various aspects of our study. Colletotrichum acutatum Simmonds isolate Goff, C. fragariae Brooks isolate CF-63, and C. gloeosporioides (Penz.) Penz. \& Sacc. in Penz. isolate CG162 were provided by B. J. Smith and have previously been included in fungicide studies $(21,22)$; Phomopsis viticola Sacc. and $P$. obscurans (Ellis \& Everh.) Sutton were obtained from M. Ellis, Ohio State University; and Fusarium oxysporum Schlechtend.:Fr. and Botrytis cinerea Pers.:Fr. were isolated by D. E. Wedge. The strains of Colletotrichum spp. and $P$. obscurans were isolated from strawberry (Fragaria $\times$ ananassa Duchesne ex. Rozier). $P$. viticola and $B$. cinerea were isolated from commercial grape (Vitis vinifera L.). $F$. oxysporum was isolated from orchid (Cycnoches sp.). Fungi were grown on potato dextrose agar (PDA; Difco, Detroit, MI) in 9-cm petri dishes and incubated under cool-white fluorescent lights $\left(55 \pm 5 \mu \mathrm{mol} \cdot \mathrm{m}^{-2} \cdot \mathrm{s}^{-1}\right)$ with a $12-\mathrm{h}$ photoperiod in a growth chamber at $24 \pm$ $2^{\circ} \mathrm{C}$, except for $B$. cinerea which was incubated at $18 \pm 2{ }^{\circ} \mathrm{C}$.

Conidial suspension preparation. Conidia were harvested from 7- to 10-day-old cultures by flooding plates with $10 \mathrm{ml}$ of sterile distilled water and dislodging conidia by softly brushing the colonies with an Lshaped plastic rod. Aqueous conidial suspensions were filtered through sterile Miracloth (Calbiochem-Novabiochem Corp., La Jolla, CA) to remove hyphae. Conidial concentrations were determined photometrically from a standard curve based on absorbance at $625 \mathrm{~nm}(4,27)$, and suspensions were then adjusted with sterile 
water to a concentration of $10^{6}$ conidia/ml.

The effect of washing the conidia on germination time was determined for each fungal species. The conidial matrix that inhibits germination was removed from each conidial suspension by centrifuging the conidial suspension at 3,000 rpm (Sorvall RC 5C Plus Centrifuge, Asheville, $\mathrm{NC}$ ) for $10 \mathrm{~min}$ at $4^{\circ} \mathrm{C}$, discarding the supernatant, and resuspending the conidial pellet in sterile distilled water by vortexing for $10 \mathrm{~s}$ (VWR Voxtexer 2, Scientific Industries, Inc., Bohemia, NY). This procedure was followed three times. The final pellet was refrigerated overnight at $4^{\circ} \mathrm{C}$. Each pellet was resuspended in Roswell Park Memorial Institute 1640 (RPMI; Life Technologies, Grand Island, NY) mycological liquid medium prepared with 16.2 $\mathrm{g}$ of RPMI buffered with $34.5 \mathrm{~g}$ of $3-[\mathrm{N}-$ morpholino] propanesulfonic acid per liter (MOPS; Sigma Chemical Co., St. Louis, MO). Both washed and unwashed conidia were adjusted to a final concentration of approximately $10^{6}$ conidia $/ \mathrm{ml}$. Conidial germination times were evaluated noting the time at which approximately $90 \%$ germination was achieved. Each species was replicated two times in each of three experiments, except for $F$. oxysporum, which had only two experiments.

Conidial germination times were evaluated by analysis of variance (ANOVA) using the GLM procedure of Statistical Analysis Systems (SAS) software, ver. 8 (SAS Institute, Inc., Cary, NC). A significance level of $P=0.05$ was used for pairwise comparisons between germination times of washed and unwashed conidia.

Germination and morphology microbioassays of natural product-based and conventional fungicides. A 24-well cell culture cluster (Corning Inc., Corning, NY) was used to grow the cultures of $B$. cinerea, $C$. acutatum, $C$. fragariae, $C$. gloeosporioides, F. oxysporum, P. viticola, and $P$. obscurans. We used technical grade natural product-based fungicides (sampangine and one sampangine analog, 4bromosampangine, synthesized at the USDA-ARS, National Center for Natural Products Research, University, MS) and seven conventional fungicides (Table 1) purchased as pesticide standards at Chem Service (West Chester, PA) representing various fungicide classes that are widely used by the fruit and ornamental industries. Each of the natural product-based and conventional fungicides was dissolved in $95 \%$ ethanol at $12 \mathrm{mM}$; sonicated for 10 min; and diluted to $1.2,0.12$, and 0.012 $\mathrm{mM}$ concentrations. Eighty microliters of each of the three concentrations of fungicide were mixed with $320 \mu$ l of buffered RPMI and $400 \mu \mathrm{l}$ of conidial suspension to obtain fungicide concentrations of 30, 3.0, and $0.3 \mu \mathrm{M}$, respectively. Fungicide concentrations were chosen based on the solubilities of the compounds, the usual range of efficacy of these conventional fungicides, and their efficacy against our test pathogens in our microtiter assay (30). An $800-\mu \mathrm{l}$ aliquot of buffered fungicide solution with conidial suspension was placed into each well of the 24-well cell culture clusters with a sterilized 13-mm-diameter cover glass (Fisherbrand, Pittsburgh, PA) at the bottom of the well. Fungi were grown in RPMI without fungicide as a control under the same conditions as the experimental group.

Fungi were incubated under the temperature and light conditions described in the "Fungal isolates and medium" section. Conidial germination was assessed by estimating the time at which $90 \%$ germination was achieved in a given well using an inverted microscope (Olympus IX 70; Olympus America, Inc., Melville, NY). Slides were made within $2 \mathrm{~h}$ of germination to document approximate germination times by inverting the cover glasses from the wells in drops of $1 \%$ lactophenol cot- ton blue (23), and sealing them with transparent fingernail polish. Close adherence to germination times was impossible due to the large number of treatments and replicas handled simultaneously. Photographs were taken with a PM-35 DX Olympus camera (Olympus America). The experiment was repeated three times.

Microtiter assay. A 96-well cell culture cluster was prepared for each replicate of each fungal isolate. Two hundred microliters of buffered fungicide solution containing the conidial suspension ("Conidial suspension preparation" section) was placed in each well of the 96-well cell culture clusters (Corning, Inc., Corning, $\mathrm{NY}$ ) at fungicide concentrations of 0.3 , 3.0, and $30 \mu \mathrm{M}$. Each compound was evaluated in triplicate against a noninoculated well (reagent blank) containing test compound and RPMI at each concentration. Well cell culture clusters were incubated in a growth chamber ("Fungal isolates and medium" section) for $72 \mathrm{~h}$ to allow time for mycelial development past the initial germination times. Growth was evaluated by measuring absorbance of each well at $620 \mathrm{~nm}$ using a microplate photometer (Packard Spectra Count; Packard Instrument Co., Downers Grove, IL). Differences in mycelial growth in vitro demonstrated the sensitivity of fungal plant pathogens to natural product-based and conventional fungicides with known modes of action (25).

Within each 96-well cell culture cluster, 16 wells containing RPMI and conidial suspension served as unamended (positive) controls and eight wells containing RPMI without conidial suspension were used as negative controls. Each test fungicide was run in duplicate at each concentration, and the experiment (duplicate) was repeated independently three times. Treatments were arranged as a split-plot design where whole plots were the seven fungal isolates and subplots were the nine chemicals at

Table 1. Chemical name, chemical class, mode of action, Fungicide Resistance Action Committee (FRAC) group, systemic activity, range of controlled pathogens, and commercial rate range of fungicides used in this study based on fungicide labels and FRAC website (http://www.frac.info)

\begin{tabular}{|c|c|c|c|c|c|c|}
\hline Fungicide & Chemical class & Mode of action & $\begin{array}{l}\text { FRAC } \\
\text { group }\end{array}$ & $\begin{array}{l}\text { Systemic } \\
\text { activity }\end{array}$ & $\begin{array}{l}\text { Range of controlled } \\
\text { pathogens }\end{array}$ & $\underset{\text { range }^{\mathrm{z}}}{\text { Commercial rate }}$ \\
\hline 4-Bromosampangine & Sampangine & ? & ? & $?$ & Colletotrichum and Botrytis & ? \\
\hline Sampangine & Sampangine & $?$ & $?$ & $?$ & $\begin{array}{l}\text { Colletotrichum, Botrytis, } \\
\text { and Phomopsis }\end{array}$ & $?$ \\
\hline Benomyl & $\begin{array}{l}\text { Methyl benzimidazole } \\
\text { carbamate }\end{array}$ & $\begin{array}{l}\text { Inhibition of microtubule } \\
\text { assembly }\end{array}$ & 1 & Systemic & Broad spectrum & $\begin{array}{l}\text { No longer comer- } \\
\text { cially available }\end{array}$ \\
\hline Captan & Multisite/phthalamide & Multisite inhibitor & M4 & Nonsystemic & Broad spectrum & $1.68-4.48 \mathrm{~kg}$ a.i./ha \\
\hline Cyprodinil & Anilinopyrimidine & $\begin{array}{l}\text { Proposed methionine } \\
\text { biosynthesis }\end{array}$ & 9 & Systemic & $\begin{array}{l}\text { Monilinia, Cladosporium, } \\
\text { and Venturia }\end{array}$ & $157-525 \mathrm{~g}$ a.i./ha \\
\hline Fenbuconazole & $\begin{array}{l}\text { Demethylation } \\
\text { inhibitor (DMI) }\end{array}$ & $\begin{array}{l}\text { Sterol biosynthesis (14- } \\
\text { demethylase inhibitor) }\end{array}$ & 3 & Nonsystemic & Monilinia and Cladosporium & 105-210 g a.i./ha \\
\hline Fenhexamid & Hydroxyanilide & $\begin{array}{l}\text { Ketoreductase inhibitor } \\
\text { (sterol biosynthesis) }\end{array}$ & 17 & Nonsystemic & Botrytis and Monilinia & $560-840 \mathrm{~g}$ a.i./ha \\
\hline Iprodione & Dicarboxymide & $\begin{array}{l}\text { Proposed NADH } \\
\text { cytochrome } \mathrm{c} \text { in lipid } \\
\text { peroxidation }\end{array}$ & 2 & Nonsystemic & Broad spectrum & 560-1,120 g a.i./ha \\
\hline Kresoxim-methyl & $\begin{array}{l}\text { Quinone outside } \\
\text { inhibitor (QoI) }\end{array}$ & $\begin{array}{l}\text { QoI complex } 3 \\
\text { respiration inhibitor }\end{array}$ & 11 & Nonsystemic & Broad spectrum & $112-280 \mathrm{~g}$ a.i./ha \\
\hline
\end{tabular}

${ }^{\mathrm{z}}$ Per application based on US-EPA Section 3 registrations. 
the three doses (21 treatments). Mean absorbance values and standard errors were used to evaluate fungal growth of $B$. cinerea, Colletotrichum spp., and $F$. oxysporum at 48 and $72 \mathrm{~h}$ at each concentration of the test compound. Mean absorbance values were expressed as percent inhibition/ stimulation using the formula: \% Inhibition $/$ stimulation $=[($ mean sample absorbance) - (mean unamended absorbance) $] \times$ 100/(mean unamended absorbance). Positive numbers indicate stimulation of growth and negative numbers indicate inhibition of growth compared to the growth of the fungus on unamended medium.

Each dose level and response time was analyzed separately by ANOVA using SAS software, ver. 8. Mean separations were performed based on least significant difference $(\mathrm{LSD})(P=0.05)$. Statistical comparisons were made of fungal growth within each concentration of fungicide for each isolate and within each concentration of fungicide across fungal isolates.

\section{RESULTS}

Germination and morphology microbioassays of natural product-based and conventional fungicides. Conidial washes to remove innate germination inhibitors considerably reduced germination times for all seven species (Table 2). Germination times were assessed against an unwashed control at the time approximately $90 \%$ of the control conidia had germinated. The reduction of conidial germination time was greatest for the two Phomopsis spp. in which the washed conidia germinated more than $20 \mathrm{~h}$ earlier than the unwashed conidia. Reducing germination times enhanced germination synchrony of each fungal species, thus improving the precision of the microtiter assays.

The stages of fungal development we recognized included incipient germ tube, germination, hyphal development, and mycelial development. For the purpose of this study, an incipient germ tube was defined as a germ tube being largely surrounded by parental conidial wall (Fig. 1A), germination was defined as a germ tube being largely composed of new wall material (Fig. 1B, C, and E), and hyphal development indicates a single, possibly branched hypha that grades into mycelial development with several or numerous hyphal branches. Qualitative assessment of fungal development is presented in Table 3. Degrees of development expressed in Table 3 cannot be compared across species, but were assessed at the times of germination for each respective species with three washes (Table 2).

The most sensitive fungal species in this experiment was $P$. obscurans with conidial germination inhibited by all test compounds except fenhexamid at $0.3 \mu \mathrm{M}$ (Table 3). Almost equally sensitive was $B$. cinerea, in which conidial germination was inhibited by all fungicides except the conventional fungicide captan at $0.3 \mu \mathrm{M}$ and the natural product-based 4-bromosampangine at 0.3 and $3.0 \mu \mathrm{M}$. The least sensitive species was $P$. viticola, in which conidial germination was only inhibited by sampangine at all rates and kresoximmethyl at $30 \mu \mathrm{M}$. Almost as insensitive was $F$. oxysporum, in which conidial germination was inhibited by kresoximmethyl and sampangine $(\geq 3.0 \mu \mathrm{M})$ and by benomyl and captan $(30 \mu \mathrm{M})$.

When comparing fungicide efficacy at the 3.0- $\mu \mathrm{M}$ concentration, the most effective conventional fungicide was kresoximmethyl, which prevented germination of all fungal species except $P$. viticola. Benomyl and fenbuconazole were almost as effective as kresoxim-methyl. Captan and fenhexamid prevented conidial germination of B. cinerea, C. fragariae, C. gloeosporioides, and P. obscurans (Table 3). Iprodione was the least effective conventional fungicide for inhibiting germination.

The natural product sampangine at 3.0 $\mu \mathrm{M}$ inhibited conidial germination in all fungal species except $C$. acutatum (Table 3), which was inhibited from further growth when assessed in the microtiter assay at about $48 \mathrm{~h}$. The analog, 4bromosampangine, at $3.0 \mu \mathrm{M}$ only, inhibited germination in $P$. obscurans, but it was the only fungicide observed to affect subsequent germ tube development causing

Table 2. Mean conidial germination time (h) ${ }^{\mathrm{x}}$ of seven plant pathogenic fungal species on 24-well cell culture clusters following zero or three washes

\begin{tabular}{lccc}
\hline Fungus & 0 washes & 3 washes & F test $^{\mathbf{y}}$ \\
\hline Botrytis cinerea & $22.3 \mathrm{a}^{\mathrm{z}}$ & $18.8 \mathrm{~b}$ & $* * * *$ \\
Colletotrichum acutatum & $14.8 \mathrm{a}$ & $8.8 \mathrm{~b}$ & $* * *$ \\
C. fragariae & $14.5 \mathrm{a}$ & $10.8 \mathrm{~b}$ & $* * *$ \\
C. gloeosporioides & $15.3 \mathrm{a}$ & $9.2 \mathrm{~b}$ & $* * *$ \\
Fusarium oxysporum & $17.0 \mathrm{a}$ & $13.0 \mathrm{~b}$ & $* * *$ \\
Phomopsis obscurans & $93.8 \mathrm{a}$ & $68.7 \mathrm{~b}$ & $* * *$ \\
P. viticola & $93.7 \mathrm{a}$ & $72.5 \mathrm{~b}$ & $* * *$ \\
\hline
\end{tabular}

${ }^{x}$ Values are means of three studies with two replications each. Since there was not a significant interaction between study and number of washes for any species, data from the three studies were combined for each species. (F. oxysporum was run twice with two replications each).

${ }^{\text {y }} F$ test: *** significant at $P<0.0001$.

${ }^{\mathrm{z}}$ Values in the same row that do not share a common letter were significantly different in a mean separation test using Fisher's protected $\operatorname{LSD}(P<0.05)$. two morphological anomalies during the time frame of this study. Colletotrichum spp. occasionally produce two germ tubes, but in the presence of this sampangine analog, two or more germ tubes were observed more commonly than was usual for C. fragariae at approximately $10 \mathrm{~h}(<10 \%$ of the conidia, qualitative observation; Fig. 1D). More significantly, germ tubes in $B$. cinerea splayed and branched in the presence of this analog at approximately $18 \mathrm{~h}$ ( $<10 \%$ of the conidia, qualitative observation; Fig. 1F). No morphological anomalies were observed in $C$. acutatum, $C$. gloeosporioides, F. oxysporum, P. obscurans, or P. viticola.

Microtiter assay. Data for fungal efficacy against Phomopsis spp. are not reported because the data had unacceptably high standard errors. Neither species achieved an acceptable level of synchronous growth or achieved $100 \%$ germination. Among isolates of the other species, there was a significant interaction between fungal isolate and fungicide concentration; therefore comparisons of fungal growth were made within each concentration of each fungicide for each isolate and within each concentration of fungicide across fungal isolates.

The sensitivity of the five species to sampangine, 4-bromosampangine, and seven conventional fungicides was assessed by measuring fungal growth in vitro relative to their growth in untreated controls. After $72 \mathrm{~h}$, growth of the most sensitive fungus, $B$. cinerea, was inhibited by benomyl, cyprodinil, fenbuconazole, fenhexamid, kresoxim-methyl, and sampangine (Table 4). All three species of Colletotrichum were inhibited by captan, cyprodinil, and sampangine. In addition, C. fragariae was sensitive to benomyl, fenbuconazole, and kresoxim-methyl. $C$. gloeosporioides was sensitive to 4bromosampangine, fenbuconazole, and kresoxim-methyl. F. oxysporum was sensitive to captan, kresoxim-methyl, and sampangine.

Comparative efficacy of conventional and natural product-based fungicides on the growth response of the plant pathogenic fungi was similar between $48 \mathrm{~h}$ (data not shown) and $72 \mathrm{~h}$ (Table 4), except for kresoxim-methyl which lost efficacy against the three species of Colletotrichum and against $F$. oxysporum, benomyl which lost efficacy against $F$. oxysporum, and iprodione which actually stimulated all Colletotrichum spp. and $F$. oxysporum. Benomyl inhibited growth of $B$. cinerea, $C$. fragariae, and $F$. oxysporum. It was less effective against $C$. gloeosporioides and actually stimulated $C$. acutatum. Captan was not highly efficacious against growth of $B$. cinerea, but it inhibited growth in the three species of Colletotrichum and $F$. oxysporum. Cyprodinil inhibited $B$. cinerea and all three species of Colletotrichum. Fenbuconazole inhibited $B$. cinerea, $C$. 
fragariae, and C. gloeosporioides. Fenhexamid, iprodione, and kresoxim-methyl inhibited growth of $B$. cinerea. The sampangine analog 4-bromosampangine inhibited growth of $C$. gloeosporioides. Sampangine was effective against all tested fungi.

\section{DISCUSSION}

We followed the microtiter assay methods of Wedge and Kuhajek (27) with the addition of washing conidia to reduce variability in percent germination and the time to maximum germination. Washing conidia removed natural germination inhibitors contained in the conidial matrix $(1,9,12,20)$, reduced germination times, and increased cultural synchrony of all fungal species. This modification improved the reliability and reproducibility of the microtiter assays and reduced experimental error associated with growth measurement or error bias. Furthermore, we found cultural synchrony to be an important criterion for selecting fungal species appropriate for microtiter assays. Conidial concentrations between $10^{5}$ and $10^{6}$ conidia/ml ensured the appropriate amount of conidial suspension to assess germination levels of selected plant pathogenic fungi precisely and accurately. The incorporation of Roswell Park Memorial Institute mycological liquid medium 1640 (RPMI) as the carbon source provided adequate germination levels in a reasonable time, plus it provided the advantage of knowing the exact composition of the medium (27). Finally, the novel use of glass coverslips in each well of the 24-well cell culture clusters provided a convenient method for achieving high-quality microscopic observations that allowed us to document the effect of fungicides on fungal developmental morphology. Photometric readings are useful for estimating percent germination that resulted from increased biomass, but those readings cannot distinguish developmental stages of fungal growth (i.e., conidial germination, germ tube elongation, hyphal development, and mycelial development).

Sampangine represents a possible alternative to conventional fungicides now used to control economically important plant pathogenic fungi such as $F$. oxysporum. Although sampangine was not the most effective fungicide against $B$. cinerea, it was nevertheless effective. Kresoximmethyl had the broadest spectrum among the conventional fungicides we tested, preventing both early germination as assessed in our direct observational experiments (ca. 9 to $19 \mathrm{~h}$ ) and delayed subsequent growth as assessed in our microtiter experiments at $48 \mathrm{~h}$, but its efficacy was largely lost by $72 \mathrm{~h}$. Sampangine was almost as broadly efficacious as kresoximmethyl at inhibiting germination in all fungi except $C$. acutatum, and it retained its efficacy through $72 \mathrm{~h}$. The potential benefits and broad spectrum antifungal activity exhibited by sampangine make it a promising candidate for further greenhouse testing. Results from preliminary greenhouse experiments demonstrated the protective activity of sampangine by reducing leaf lesions when applied to the host prior to inoculation with $C$. fragariae (D. E. Wedge and B. J. Smith, unpublished data).

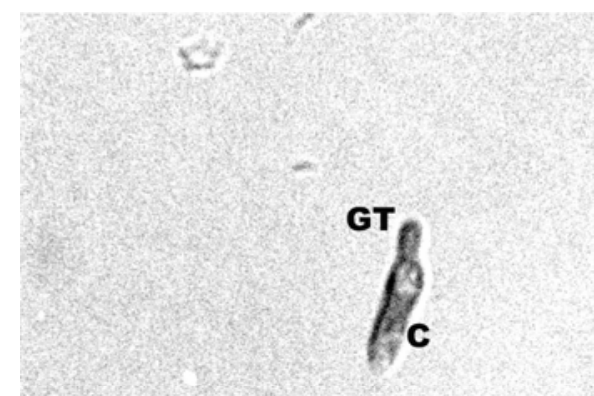

A

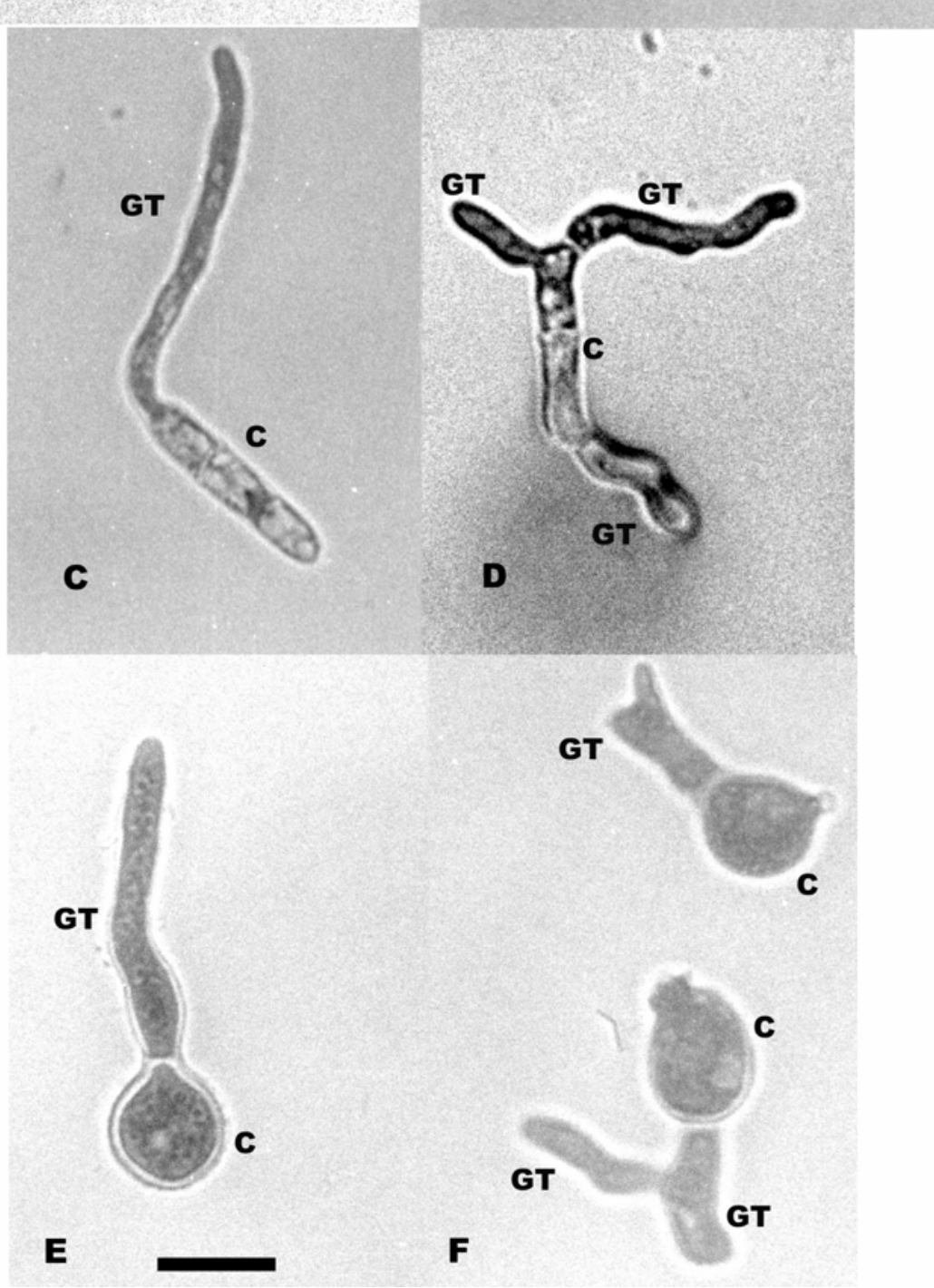

Fig. 1. The effect of fungicides on conidial germination. A, Incipient germination of conidia of Colletotrichum acutatum in the presence of iprodione at a concentration of $3.0 \mu \mathrm{M} ; \mathbf{B}$, normal conidial germination of $C$. gloeosporioides in the presence of captan at a concentration of $0.3 \mu \mathrm{M} ; \mathbf{C}$, normal germ tube development and $\mathbf{D}$, anomalous germ tube branching of $C$. fragariae challenged with 0.3 $\mu \mathrm{M}$ 4-bromosampangine; $\mathbf{E}$, normal germ tube development and $\mathbf{F}$, splayed (upper) and branched (lower) germ tubes of Botrytis cinerea challenged with $0.3 \mu \mathrm{M}$ 4-bromosampangine. $\mathrm{C}=$ conidium, $\mathrm{GT}=$ germ tube. $\mathrm{Bar}=10 \mu \mathrm{m}$. gens for a wide range of commercially sensitivity to fungicides and considered their suitability as test organisms in this study. Phomopsis spp. were not suitable for the microtiter assay due to their asynchronous germination, which prevented reliable absorbance readings. Hyphal
The fungi used in this study are pathoimportant crops. We have assessed their

\section{a}


growth after conidial germination for these species requires several days. As a result, the sensitivity and reproducibility of the method (absorbance) is diminished, since hyphal growth obscures low germination.
Among the other five species, $B$. cinerea was generally the most sensitive to fungicides and $F$. oxysporum was the least sensitive. These represent good controls for this type of study because they demonstrate the extremes of fungicide efficacy. The three species of Colletotrichum exhibited various degrees of sensitivity, thus demonstrating the specific efficacy of various fungicides that are not otherwise broad

Table 3. Effects of conventional and natural product-based fungicides on growth and development of selected plant pathogenic fungi in a germination and morphology assayw

\begin{tabular}{|c|c|c|c|c|c|c|c|c|c|c|c|c|c|c|c|c|c|c|c|c|c|}
\hline \multirow{3}{*}{$\frac{\text { Control }^{\mathrm{x}}}{{\text { Concentration }(\mu \mathrm{M})^{\mathrm{z}}}^{\mathrm{z}}}$} & \multirow{2}{*}{\multicolumn{3}{|c|}{$\begin{array}{c}\begin{array}{c}\text { Botrytis } \\
\text { cinerea }\end{array} \\
+^{\mathbf{y}}\end{array}$}} & \multirow{2}{*}{\multicolumn{3}{|c|}{$\begin{array}{c}\begin{array}{c}\text { Colletotrichum } \\
\text { acutatum }\end{array} \\
++\end{array}$}} & \multirow{2}{*}{\multicolumn{3}{|c|}{$\begin{array}{c}\text { C. fragariae } \\
+\end{array}$}} & \multirow{2}{*}{\multicolumn{3}{|c|}{$\begin{array}{c}C . \\
\text { gloeosporioides } \\
++\end{array}$}} & \multirow{2}{*}{\multicolumn{3}{|c|}{$\begin{array}{c}\begin{array}{c}\text { Fusarium } \\
\text { oxysporum }\end{array} \\
+\end{array}$}} & \multirow{2}{*}{\multicolumn{3}{|c|}{$\begin{array}{c}\begin{array}{c}\text { Phomopsis } \\
\text { obscurans }\end{array} \\
+++\end{array}$}} & \multicolumn{3}{|c|}{ P. viticola } \\
\hline & & & & & & & & & & & & & & & & & & & & ++ & \\
\hline & 0.3 & 3.0 & 30 & 0.3 & 3.0 & 30 & 0.3 & 3.0 & 30 & 0.3 & 3.0 & 30 & 0.3 & 3.0 & 30 & 0.3 & 3.0 & 30 & 0.3 & 3.0 & 30 \\
\hline Benomyl & - & - & - & - & - & - & $\sim$ & - & - & $\sim$ & - & - & + & + & - & - & - & - & + & + & + \\
\hline Captan & + & - & - & - & + & - & + & - & - & ++ & - & - & ++ & + & - & - & - & - & ++ & ++ & ++ \\
\hline Cyprodinil & - & - & - & + & - & - & $\sim$ & $\sim$ & - & $\sim$ & $\sim$ & - & ++ & + & + & - & - & - & +++ & + & + \\
\hline Fenbuconazole & - & - & - & - & - & - & $\sim$ & $\sim$ & $\sim$ & - & - & - & + & + & + & - & - & - & + & + & + \\
\hline Fenhexamid & - & - & - & + & + & - & + & - & - & + & - & - & ++ & ++ & + & + & - & - & +++ & ++ & + \\
\hline Iprodione & - & - & - & + & + & - & + & $\sim$ & - & + & + & - & ++ & + & + & - & - & - & +++ & ++ & + \\
\hline Kresoxim-methyl & - & - & - & - & - & - & - & - & - & - & - & - & + & - & - & - & - & - & +++ & + & - \\
\hline 4-Bromosampangine & + & + & - & ++ & ++ & ++ & + & + & + & + & + & + & + & + & + & - & - & - & + & + & + \\
\hline Sampangine & - & - & - & + & + & + & + & - & - & + & - & - & + & - & - & - & - & - & - & - & - \\
\hline
\end{tabular}

wEach species was assessed within $2 \mathrm{~h}$ of the time of germination with three washes.

${ }^{x}$ Growth medium without any fungicide.

y Growth is indicated by the following symbols: $-=$ no germination, $\sim=$ germination $<90 \%,+=$ germination approximately $90 \%,++=$ germination $>90 \%$ but less than $100 \%,+++=$ virtually all conidia germinated. Note that qualitative levels of germination cannot be compared across species due to inherent species differences in growth rates and delayed times for beginning observations (due to the large number of simultaneous observations required).

${ }^{\mathrm{z}}$ Concentration of fungicides incorporated into growth medium.

Table 4. Sensitivity of fungi to fungicides ${ }^{\mathrm{w}}$

\begin{tabular}{|c|c|c|c|c|c|c|}
\hline $\begin{array}{l}\text { Concentration }^{\mathrm{x}} \\
\text { Fungicide }\end{array}$ & $\begin{array}{l}\text { Botrytis } \\
\text { cinerea }\end{array}$ & $\begin{array}{c}\text { Colletotrichum } \\
\text { acutatum }\end{array}$ & C. fragariae & C. gloeosporioides & $\begin{array}{c}\text { Fusarium } \\
\text { oxysporum }\end{array}$ & $\mathbf{L S D}_{0.05}$ \\
\hline \multicolumn{7}{|l|}{$0.3 \mu \mathrm{M}$} \\
\hline 4-Bromosampangine & $-48 c^{y}, B^{z}$ & $-7 \mathrm{~cd}, \mathrm{~A}$ & $-15 \mathrm{~b}, \mathrm{~A}$ & $-99 \mathrm{~d}, \mathrm{C}$ & $-3 a b, A$ & 24 \\
\hline Sampangine & $-18 \mathrm{~b}, \mathrm{AB}$ & $-6 \mathrm{~cd}, \mathrm{~A}$ & $-33 b c, B$ & $-33 \mathrm{~b}, \mathrm{~B}$ & $-5 \mathrm{ab}, \mathrm{A}$ & 22 \\
\hline Benomyl & $-97 \mathrm{~d}, \mathrm{D}$ & $8 \mathrm{bc}, \mathrm{A}$ & $-37 \mathrm{c}, \mathrm{C}$ & $-16 \mathrm{~b}, \mathrm{~B}$ & $2 \mathrm{a}, \mathrm{AB}$ & 18 \\
\hline Captan & $25 \mathrm{a}, \mathrm{A}$ & $10 \mathrm{abc}, \mathrm{B}$ & $15 \mathrm{a}, \mathrm{AB}$ & $15 \mathrm{a}, \mathrm{AB}$ & $5 \mathrm{a}, \mathrm{B}$ & 14 \\
\hline Cyprodinil & $-90 \mathrm{~d}, \mathrm{C}$ & $-85 \mathrm{e}, \mathrm{C}$ & $-83 \mathrm{~d}, \mathrm{C}$ & $-56 \mathrm{c}, \mathrm{B}$ & $5 \mathrm{a}, \mathrm{A}$ & 9 \\
\hline Fenbuconazole & $-83 \mathrm{~d}, \mathrm{D}$ & $16 \mathrm{ab}, \mathrm{A}$ & 19 a, A & $-59 \mathrm{c}, \mathrm{C}$ & $-10 \mathrm{~b}, \mathrm{~B}$ & 19 \\
\hline Fenhexamid & $-98 \mathrm{~d}, \mathrm{C}$ & $20 \mathrm{ab}, \mathrm{A}$ & $13 \mathrm{a}, \mathrm{AB}$ & $11 \mathrm{a}, \mathrm{AB}$ & $0 \mathrm{ab}, \mathrm{B}$ & 17 \\
\hline Iprodione & $24 \mathrm{a}, \mathrm{A}$ & 27 a, A & 17 a, A & 18 a, A & $2 \mathrm{a}, \mathrm{A}$ & 35 \\
\hline Kresoxim-methyl & $-97 \mathrm{~d}, \mathrm{C}$ & $-18 \mathrm{~d}, \mathrm{~A}$ & $-36 \mathrm{c}, \mathrm{A}$ & $-59 \mathrm{c}, \mathrm{B}$ & $-30 \mathrm{c}, \mathrm{A}$ & 18 \\
\hline $\mathrm{LSD}_{0.05}$ & 19 & 18 & 18 & 20 & 2 & \\
\hline \multicolumn{7}{|l|}{$3.0 \mu \mathrm{M}$} \\
\hline 4-Bromosampangine & $-59 \mathrm{c}, \mathrm{C}$ & $-25 \mathrm{~b}, \mathrm{AB}$ & $-46 \mathrm{c}, \mathrm{BC}$ & $-99 \mathrm{~d}, \mathrm{D}$ & $-14 \mathrm{bc}, \mathrm{A}$ & 23 \\
\hline Sampangine & $-79 \mathrm{~d}, \mathrm{~B}$ & $-90 \mathrm{~d}, \mathrm{BC}$ & $-97 \mathrm{f}, \mathrm{C}$ & $-99 \mathrm{~d}, \mathrm{C}$ & $-43 \mathrm{e}, \mathrm{A}$ & 11 \\
\hline Benomyl & $-94 \mathrm{e}, \mathrm{C}$ & $15 \mathrm{a}, \mathrm{A}$ & -93 ef, $C$ & $-60 \mathrm{~b}, \mathrm{~B}$ & $-1 \mathrm{a}, \mathrm{A}$ & 19 \\
\hline Captan & $-2 \mathrm{a}, \mathrm{A}$ & $-99 \mathrm{~d}, \mathrm{C}$ & $-98 \mathrm{f}, \mathrm{C}$ & $-98 \mathrm{~d}, \mathrm{C}$ & $-24 \mathrm{~cd}, \mathrm{~B}$ & 20 \\
\hline Cyprodinil & $-97 \mathrm{e}, \mathrm{C}$ & $-95 \mathrm{~d}, \mathrm{C}$ & $-84 \mathrm{e}, \mathrm{B}$ & $-84 \mathrm{~cd}, \mathrm{~B}$ & $-6 \mathrm{ab}, \mathrm{A}$ & 7 \\
\hline Fenbuconazole & -93 e, C & $6 \mathrm{a}, \mathrm{A}$ & $5 \mathrm{~b}, \mathrm{~A}$ & $-98 \mathrm{~d}, \mathrm{C}$ & $-29 \mathrm{~d}, \mathrm{~B}$ & 20 \\
\hline Fenhexamid & $-97 \mathrm{e}, \mathrm{C}$ & $11 \mathrm{a}, \mathrm{A}$ & $10 \mathrm{~b}, \mathrm{AB}$ & $16 \mathrm{a}, \mathrm{A}$ & $-4 a b, B$ & 14 \\
\hline Iprodione & $-40 \mathrm{~b}, \mathrm{C}$ & $22 \mathrm{a}, \mathrm{A}$ & $24 \mathrm{a}, \mathrm{A}$ & $31 \mathrm{a}, \mathrm{A}$ & $4 \mathrm{a}, \mathrm{B}$ & 17 \\
\hline Kresoxim-methyl & $-97 \mathrm{e}, \mathrm{D}$ & $-48 \mathrm{c}, \mathrm{A}$ & $-72 \mathrm{~d}, \mathrm{~B}$ & $-83 \mathrm{c}, \mathrm{C}$ & $-66 \mathrm{f}, \mathrm{B}$ & 9 \\
\hline $\mathrm{LSD}_{0.05}$ & 12 & 20 & 12 & 15 & 12 & \\
\hline \multicolumn{7}{|l|}{$30 \mu \mathrm{M}$} \\
\hline 4-Bromosampangine & $-32 \mathrm{a}, \mathrm{A}$ & $-11 \mathrm{~cd}, \mathrm{~A}$ & $-27 \mathrm{~b}, \mathrm{~A}$ & $-100 \mathrm{~d}, \mathrm{~B}$ & $-9 \mathrm{~b}, \mathrm{~A}$ & 25 \\
\hline Sampangine & $-98 \mathrm{~b}, \mathrm{~A}$ & $-100 \mathrm{f}, \mathrm{B}$ & $-100 \mathrm{c}, \mathrm{B}$ & $-100 \mathrm{~d}, \mathrm{~B}$ & $-100 \mathrm{f}, \mathrm{B}$ & 1 \\
\hline Benomyl & -96 b, C & $15 \mathrm{~b}, \mathrm{~A}$ & $-94 \mathrm{c}, \mathrm{C}$ & $-45 \mathrm{c}, \mathrm{B}$ & $-77 \mathrm{e}, \mathrm{C}$ & 20 \\
\hline Captan & $-28 \mathrm{a}, \mathrm{A}$ & $-100 \mathrm{f}, \mathrm{B}$ & $-100 \mathrm{c}, \mathrm{B}$ & $-100 \mathrm{~d}, \mathrm{~B}$ & $-100 \mathrm{f}, \mathrm{B}$ & 6 \\
\hline Cyprodinil & $-98 \mathrm{~b}, \mathrm{~B}$ & $-98 \mathrm{f}, \mathrm{B}$ & $-89 \mathrm{c}, \mathrm{B}$ & $-95 \mathrm{~d}, \mathrm{~B}$ & $-31 \mathrm{c}, \mathrm{A}$ & 10 \\
\hline Fenbuconazole & $-98 \mathrm{~b}, \mathrm{C}$ & $-22 \mathrm{~d}, \mathrm{~A}$ & $-98 \mathrm{c}, \mathrm{C}$ & $-100 \mathrm{~d}, \mathrm{C}$ & $-45 \mathrm{~d}, \mathrm{~B}$ & 13 \\
\hline Fenhexamid & -100 b, C & $-2 \mathrm{c}, \mathrm{A}$ & $-20 \mathrm{~b}, \mathrm{AB}$ & $-7 \mathrm{~b}, \mathrm{AB}$ & $-21 b c, B$ & 18 \\
\hline Iprodione & $-98 \mathrm{~b}, \mathrm{C}$ & $65 \mathrm{a}, \mathrm{A}$ & 58 a, A & 17 a, B & $11 \mathrm{a}, \mathrm{B}$ & 34 \\
\hline Kresoxim-methyl & $-99 \mathrm{~b}, \mathrm{~B}$ & $-70 \mathrm{e}, \mathrm{A}$ & $-80 \mathrm{c}, \mathrm{B}$ & $-90 \mathrm{~d}, \mathrm{C}$ & $-70 \mathrm{e}, \mathrm{A}$ & 7 \\
\hline $\operatorname{LSD}_{0.05}$ & 4 & 16 & 21 & 18 & 12 & \\
\hline
\end{tabular}

${ }^{\mathrm{w}}$ Comparative growth response of five plant pathogens in growth solution amended with three concentration levels of conventional and natural product-based fungicides compared to growth in unamended solution after $72 \mathrm{~h}$. Growth response was calculated as \% Inhibition/stimulation $=[($ mean sample absorbance) - (mean unamended absorbance) $] \times 100 /$ (mean unamended absorbance). Positive numbers indicate a stimulation of growth and negative numbers indicate an inhibition of growth compared to the growth of the fungus on unamended medium.

${ }^{x}$ Concentration of fungicides incorporated into growth medium.

${ }^{y}$ Mean values followed by different lowercase letters in the same column within a concentration within a fungus are significantly $(P=0.05)$ different as determined by least significant difference (LSD).

${ }^{\mathrm{z}}$ Mean values followed by different uppercase letters in the same row are significantly $(P=0.05)$ different as determined by LSD. 
spectrum. The five pathogenic fungal species used in our experiments (excluding Phomopsis spp.) are suitable for in vitro (28) and in planta (31) assays including fungicide efficacy, mode of action, and fungal resistance.

We found it more useful to consider the observed effects of a fungicide in terms of the "physical mode of action" (24), referring to the whole organismal, morphological level of organization, rather than the "biochemical mode of action" $(3,5)$, which entails the subcellular level of organization. Some of the fungicides obviously stop germination for some of the species in both the germination and morphology assays (direct observation) and the microtiter assays. Others allowed early germination (direct observation), but inhibited further growth (microtiter). These latter instances are biologically interesting in that they suggest a physical mode of action different from inhibition of germination.

Sampangine is an effective natural product-based fungicide whose physical mode of action is apparently to arrest conidial germination in $B$. cinerea, $C$. fragariae, $C$. gloeosporioides, and $F$. oxysporum. Our direct observation that $C$. acutatum germinates in the presence of sampangine at about $9 \mathrm{~h}$ contrasts with growth inhibition in the microtiter assay at about $48 \mathrm{~h}$. This suggests that $C$. acutatum does not respond to sampangine in the same way as the other fungi tested, yet sampangine was ultimately efficacious against this fungus.

The apparent physical mode of action of sampangine, germination inhibition, is comparable to some of the conventional fungicides tested, including captan, iprodione, and kresoxim-methyl, that also entail inhibiting conidial germination on several hosts $(3,10,16,32)$. Köller (7) discusses captan as a multisite fungal inhibitor, consistent with our observation that captan (and sampangine) did not inhibit conidial germination in C. acutatum at $9 \mathrm{~h}$, although both fungicides prevented subsequent growth measured at about $48 \mathrm{~h}$.

4-Bromosampangine was not as effective as sampangine or the conventional fungicides at inhibiting fungal germination. Direct microscopic observations of the effects of this sampangine analog indicated that germ tube development was affected not only by the presence of distorted germ tubes that branched more frequently than those of untreated conidia, but also by the emergence of multiple germ tubes, suggesting the possibility that this compound may protect the host after fungi have already established themselves in or on the host. This anomaly caused by 4-bromosampangine in germ tube development is similar to the physical mode of action observed in germinating conidia of B. cinerea (6) and Botrytis fabae (18), which when exposed to fenhexamid and benomyl, respectively, produced swollen, branched germ tubes. Additional studies also support our observations that when conidial germination is not inhibited, subsequent developmental stages such as germ tube elongation and mycelial development may be inhibited $(2,8,11,19)$.

We tested sampangine, 4-bromosampangine, and conventional fungicides for their ability to inhibit and/or delay germination or subsequent development for a short time period $(72 \mathrm{~h}$ ). The longer duration of efficacious inhibition of each fungicide was not tested in the scope of this research. Richmond and Pring (18) reported that conidia of $B$. fabae which had been completely inhibited from germinating in the presence of benomyl germinated normally when transferred to a medium free of benomyl. In addition, they reported that when B. fabae was exposed again to benomyl, germinating conidia produced swollen and distorted germ tubes that branched more frequently than the usual. However, conidia of $B$. fabae resumed normal growth when transferred to a medium free of benomyl. Furthermore, the abnormal germ tubes produced in the presence of benomyl formed a single hypha and grew normally in the absence of the fungicide. Richmond and Pring's study demonstrates that some chemicals that inhibit fungal development are fungistatic, not fungicidal, and may even allow resumed growth of the fungus when they are removed. They also demonstrated the value of direct microscopic observation of the effect of fungicides on fungi. In our study, we were able to document by direct microscopic observation the emergence of splayed and multiple germ tubes caused by 4-bromosampangine in $B$. cinerea and $C$. fragariae, respectively.

\section{ACKNOWLEDGMENTS}

We thank Mike Ellis, Ohio State University, for providing the cultures of Phomopsis viticola and $P$. obscurans used in this study. We also thank Dewayne Harries for running the statistics.

\section{LITERATURE CITED}

1. Arpin, N., and Bouillant, M. L. 1981. Light and mycosporines. Pages 435-454 in: The Fungal Spore, Morphogenetic Controls. G. Turian and H. R. Hohl, eds. Academic Press, London.

2. Duben, J., Rosslenbroich, H. J., and Jenner, G. 2002. Teldor ${ }^{\circledR}$ (Fenhexamid) - A new specific fungicide for the control of Botrytis cinerea and related pathogens on Rubus, Ribes, and other crops. Acta Hortic. 585:325-329.

3. Edlich, W., and Lyr, H. 1995. Mechanism of action of dicarboximide fungicides. Pages 119131 in: Modern Selective FungicidesProperties, Applications, Mechanisms of Action. H. Lyr, ed. Gustav Fisher Verlag, New York.

4. Espinel-Ingrof, A., and Kerkering, T. M. 1991. Spectrophotometric method of inoculum preparation for the in vitro susceptibility testing of filamentous fungi. J. Clin. Microbiol. 29:393-394.

5. Gold, R. E., Ammermann, E., Köhle, H., Leinhos, G. M. E., Lorenz, G., Speakman, J. B., Stark-Urnau, M., and Sauter, H. 1996. The synthetic strobilurin BAS $490 \mathrm{~F}$ : Profile of a modern fungicide. Pages 79-92 in: Modern Fungicides and Antifungal Compounds. $\mathrm{H}$. Lyr, P. E. Russell, and H. D. Sisler, eds. Intercept Limited, Andover, Hants, UK.

6. Hänßler, G., and Pontzen, R. 1999. Effect of fenhexamid on the development of Botrytis cinerea. Pflanzenschutz Nachr. Bayer 52:158176.

7. Köller, W. 1994. Chemical control of apple scab - status quo and future. Norw. J. Agric. Sci. S:149-170.

8. Latorre, B. A., Spadaro, I., and Rioja, M. E. 2002. Occurrence of resistant strains of Botrytis cinerea to anilinopyrimide fungicides in table grapes in Chile. Crop Prot. 21:957-961.

9. Leite, B., and Nicholson, R. L. 1992. Mycosporine-Alanine: A self-inhibitor of germination from the conidial mucilage of Colletotrichum graminicola. Exp. Mycol. 16:76-86.

10. Leroux, P. 1996. Recent developments in the mode of action of fungicides. Pestic. Sci. 47:191-197.

11. Leroux, P., Chapeland, F., Arnold, A., and Gredt, M. 1998. Résistance de Botrytis cinerea aux fungicides. Du laboratoire au vignoble et vice versa. Phytoma 504:62-67.

12. Louis, I., and Cooke, R. C. 1985. Conidial matrix and spore germination in some plant pathogens. Trans. Br. Mycol. Soc. 84:661-667.

13. Meepagala, K. M., Sturtz, G., and Wedge, D. E. 2002. Antifungal constituents of essential oil fraction of Artemisa dracunculus L. Var. dracunculus. J. Agric. Food Chem. 50:69896992.

14. Meepagala, K. M., Sturtz, G., Wise, D., and Wedge, D. E. 2002. Molluscicidal and antifungal activity of Erigeron speciosus steam distillate. Pest Manag. Sci. 58:1043-1047.

15. Oliva, A., Meepagala, K. M., Wedge, D. E., Hale, A. L., Harries, D., Aliotta, G., and Duke, S. O. 2003. Natural fungicides from Rute graveolens $\mathrm{L}$. leaves, including a new quinone alkaloid. J. Agric. Food Chem. 50:890-896.

16. Pommer, E. H., and Lorenz, G. 1982. Resistance of Botrytis cinerea Pers. to dicarboximide fungicides-literature review. Crop Prot. 1:221-230.

17. Renault, S., De Lucca II, A. J., Boue, S. M., Bland, J. M., Vigo, C. B., and Selitrennikoff, C. 2003. CAY-1, a novel antifungal compound from cayenne pepper. Med. Mycol. 41:75-81.

18. Richmond, D. V., and Pring, R. J. 1971. The effect of benomyl on the fine structure of Botrytis fabae. J. Gen. Microbiol. 66:79-94.

19. Rosslenbroich, H. J., and Stuebler, D. 2000. Botrytis cinerea - History of chemical control and novel fungicides for its management. Crop Prot. 19:557-561.

20. Seebach, D., Adam, G., von dem BusscheHunnefeld, C., Gisi, U., and Binder, H. 1989. EPC-Synthesis and fungistatic activity of a gloeosporone analog with an $\omega$-hydroxy-butyl instead of the pentyl side chain on the macrocyclic ring. Lieb. Ann. Chem. 12:1007-1012.

21. Smith, B. J., and Black, L .L. 1993. In vitro activity of fungicides against Colletotrichum fragariae. Acta Hortic. 348:509-512.

22. Smith, B. J., and Black, L .L. 1993. In vitro fungicide studies show the occurrence of benomyl-resistant Colletotrichum spp. from strawberry. Adv. Strawberry Res. 12:42-48.

23. Stevens, R.B., ed. 1974. Mycology Guidebook. University of Washington Press, Seattle.

24. Szkolnic, M. 1981. Physical modes of action of sterol-inhibiting fungicides against apple diseases. Plant Dis. 65:981-985.

25. Wedge, D. E., Curry, K. J., Boudreaux, J., Pace, P., and Smith, B. J. 2001. A microtiter assay demonstrates sensitivity and resistance profiles for Botrytis cinerea isolates from Louisiana strawberry farms. Adv. Strawberry Res. 20:27-33.

26. Wedge, D. E., Galindo, J. C., and Marcias, F. A. 2000. Fungicidal activity of natural and 
synthetic sesquiterpene lactone analogs. Phytochemistry. 53:747-757.

27. Wedge, D. E., and Kuhajek, M. A. 1998. A microbioassay for fungicide discovery. SAAS Bull. Biochem. Biotechnol. 11:1-7.

28. Wedge, D. E., and Nagle, D. G. 2000. A new 2D-TLC bioautography method for the discovery of novel antifungal agents to control plant pathogens. J. Nat. Prod. 63:1050-1054.
29. Wedge, D. E., and Nagle, D. G. 2005. Fungicidal properties of sampangine and its analogs to agriculturally important fungal plant pathogens. U.S. Patent \# 6,844,353B2; January 18, 2005

30. Wedge, D. W., and Smith, B. J. 2006. A microtiter assay shows effectiveness of a natural fungicide for control of Colletotrichum spp. (Abstr.) Phytopathology 96:S189.
31. Wedge, D. W., Smith, B. J., Quebedeaux, J. P and Constantin, R. J. 2007. Fungicide management strategies for control of strawberry fruit rot diseases in Louisiana and Mississippi. Crop Prot. 26:1449-1458.

32. Ypema, H. L., and Gold, R. E. 1999. Kresoxim-methyl: Modification of a naturally occurring compound to produce a new fungicide. Plant Dis. 83:4-19. 